\title{
Diterpenoid alkaloids from some Turkish Consolida species and their antiviral activities
}

\author{
Bilge Şener $^{\mathrm{a}, *}$, Ilkay Orhan, ${ }^{\mathrm{a}}$ and Berrin Özçelik ${ }^{\mathrm{b}}$ \\ ${ }^{a}$ Department of Pharmacognosy, Faculty of Pharmacy, Gazi University, 6330 Ankara, Turkey \\ ${ }^{b}$ Department of Pharmaceutical Microbiology, Faculty of Pharmacy, Gazi University, 6330 \\ Ankara, Turkey \\ E-mail: bilgesen@gazi.edu.tr
}

\section{Dedicated to Prof. Dr. Atta-ur-Rahman on his $65^{\text {th }}$ birthday}

\begin{abstract}
Five diterpenoid-derivative alkaloids, lycoctonine (1), 18-O-methyllycoctonine (2), delcosine (3), 14-acetyldelcosine (4), and 14-acetylbrowniine (5), were screened for their antibacterial, antifungal, and antiviral activities. Both DNA virus Herpes simplex (HSV) and RNA virus Parainfluenza (PI-3) were employed for antiviral assessment of the compounds using MadinDarby bovine kidney and Vero cell lines. Their maximum non-toxic concentrations (MNTC) and cytopathogenic effects (CPE) were determined using acyclovir and oseltamivir as the references. Antibacterial and antifungal activities of the alkaloids were tested against Escherichia coli, Pseudomonas aeruginosa, Proteus mirabilis, Klebsiella pneumoniae, Acinetobacter baumannii, Staphylococcus aureus and Bacillus subtilis, as well as the fungus; Candida albicans by microdilution method as compared to the references ampicilline, oflaxocine, and ketacanazole. The alkaloids presented a notable antibacterial effect only towards $K$. pneumoniae and $A$. baumannii $(8 \mu \mathrm{g} / \mathrm{ml})$, while they had quite considerable antifungal activity at $4 \mu \mathrm{g} / \mathrm{ml}$ concentration. On the other hand, the alkaloids were found to have selective inhibition against PI-3 virus ranging between 1 and $32 \mu \mathrm{g} / \mathrm{ml}$ as minimum and maximum CPE inhibitory concentrations, whereas they were completely inactive towards HSV.
\end{abstract}

Keywords: Diterpene alkaloids, Consolida, antibacterial, antifungal, antiviral

\section{Introduction}

The genus Consolida, Aconitum, and Delphinium (Ranunculaceae) are well-known to be rich in diterpene alkaloids, which possess a diverse range of biological activities. ${ }^{1}$ These plants have also been the cause of poisonings that primarily occur in cattle as well as human beings, due to 
toxicity of their alkaloids. ${ }^{2-5}$ The common name of Consolida sp., shared with the closely related genus Delphinium, is "larkspur". On the other hand, the therapeutic employment of natural products is as early as human progress and, as is well-known, plants can produce antimicrobial compounds to protect themselves from biotic attack that could be essential for microbial infection resistance. However, there are quite a number of antimicrobial agents of synthetic and natural origin with different potencies, whereas only a few antiviral agents are available in the market. Hence, it is rather logical to develop a move towards the screening of medicinal plant extracts along with their pure components with the goal of finding new choices for antiviral and antimicrobial agents.

For this purpose, an attempt has been made to evaluate the antiviral, antibacterial, and antifungal activities of lycoctonine (1), 18-O-methyllycoctonine (2), delcosine (3), 14acetyldelcosine (4), and 14-acetylbrowniine (5), the diterpenoid-derivative alkaloids previously isolated from some Consolida species growing in Turkey (Figure 1).

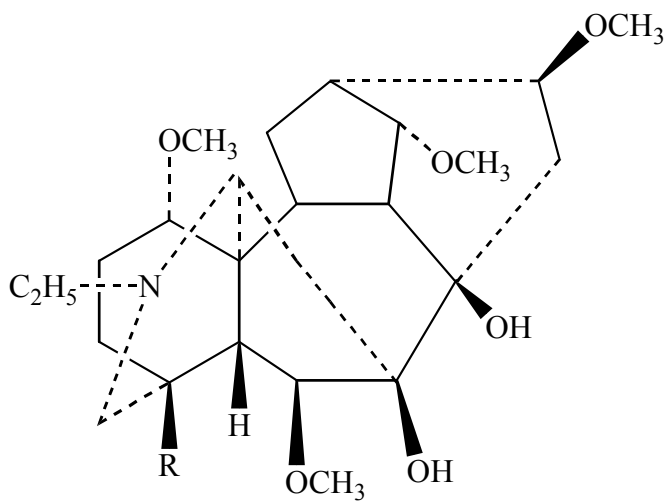
$\mathrm{R}=\mathrm{CH}_{2} \mathrm{OH}$
(1) Lycoctonine
$\mathrm{R}=\mathrm{CH}_{2} \mathrm{OCH}_{3}$
(2) 18-O-Methyllycoctonine

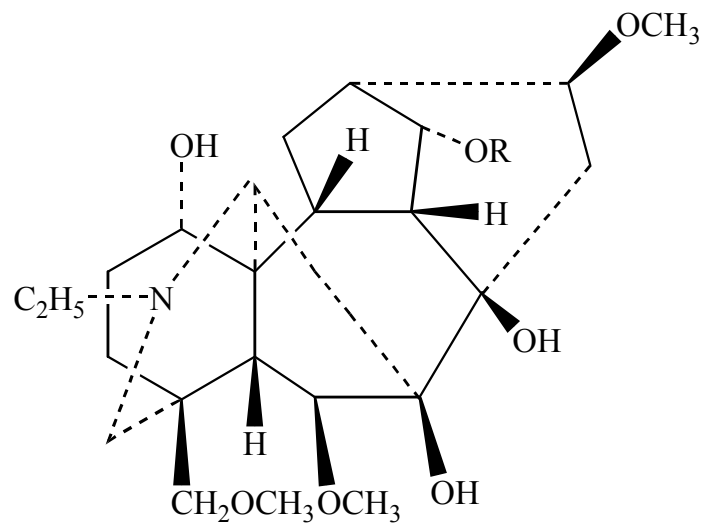
$\mathrm{R}=\mathrm{H}$
(3) Delcosine
$\mathrm{R}=\mathrm{COCH}_{3}$
(4) 14-Acetyldelcosine 


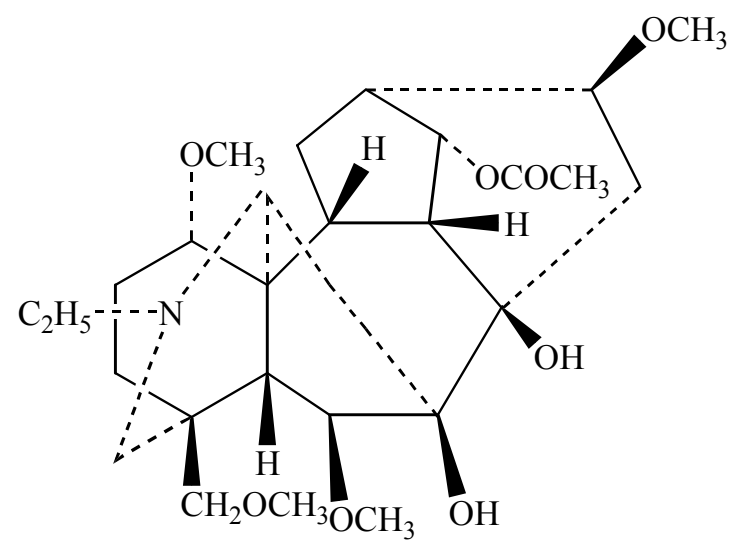

(5) 14-Acetylbrowniine

Figure 1 Chemical structures of the alkaloids 1-5.

The alkaloids were screened against the ATCC strains of Escherichia coli, Pseudomonas aeruginosa, Proteus mirabilis, Klebsiella pneumoniae, Acinetobacter baumannii, Staphylococcus aureus, Bacillus subtilis, and Candida albicans by the microdilution method. In addition, both DNA virus Herpes simplex (HSV) and RNA virus Parainfluenza (PI-3) were employed for antiviral appraisal of these diterpene alkaloids by using Madin-Darby Bovine Kidney (MDBK) and Vero cell lines.

\section{Results and Discussion}

In this study, in vitro antiviral, antibacterial, and antifungal activities of five diterpene-type of alkaloids (1-5) were determined (Figure 1). The results pointed out that these alkaloids possessed the highest antibacterial activity against K. pneumoniae and A. baumannii (Table 1) at $8 \mu \mathrm{g} / \mathrm{ml}$ concentration, whereas they were moderately active to the rest of the bacteria. However, all the alkaloids tested were highly effective against $C$. albicans in a comparable manner to ketacanazole in the antifungal screening by the microdilution method (Table 1).

Conversely, a selective inhibition was observed towards PI-3 virus by these alkaloids, while they were entirely unsuccessful on inhibition of HSV (Table 2).

The PI-3 inhibitory activity of the alkaloids was fairly analogous to that of oseltamivir, ranging between $8-32 \mu \mathrm{g} / \mathrm{ml}$ as minimum and maximum inhibitory concentrations for the cytopathogenic effect (CPE).

Up to the present time, a number of toxicity and biological activity studies have been performed either on diterpene alkaloids or the extracts obtained from Consolida, Delphinium, and Aconitum species, which are known to be a major cause for cattle loss. ${ }^{6}$ 
Table1. Antimicrobial activity of the alkaloids and standards against tested control strains as Minimum Inhibitory Concentrations (MICs) $(\mu \mathrm{g} / \mathrm{ml})$

\begin{tabular}{ccccccccc}
\hline $\begin{array}{c}\text { Microorganisms } \\
\text { Alkaloids }\end{array}$ & $\begin{array}{c}E . \\
\text { coli }\end{array}$ & $\begin{array}{c}\text { P. } \\
\text { aerugi- } \\
\text { nosa }\end{array}$ & $\begin{array}{c}\text { Pirabi- } \\
\text { lis }\end{array}$ & $\begin{array}{c}\text { K. } \\
\text { pneumo- } \\
\text { niae }\end{array}$ & $\begin{array}{c}\text { A. } \\
\text { bauman- } \\
\text { nii }\end{array}$ & $\begin{array}{c}\text { S. } \\
\text { aureus }\end{array}$ & $\begin{array}{c}B . \\
\text { subtilis }\end{array}$ & $\begin{array}{c}C . \\
\text { albicans }\end{array}$ \\
\hline Lycoctonine & 32 & 64 & 32 & 8 & 8 & 64 & 128 & 4 \\
$18-$ & 32 & 64 & 32 & 8 & 8 & 64 & 128 & 4 \\
$\begin{array}{c}\text { Omethyllycoctonine } \\
\text { Delcosine }\end{array}$ & 32 & 64 & 32 & 8 & 8 & 64 & 128 & 4 \\
14-Acetyldelcosine & 32 & 64 & 32 & 8 & 8 & 64 & 128 & 4 \\
14-Acetylbrowniine & 32 & 64 & 32 & 8 & 8 & 64 & 128 & 4 \\
Ampicilline & 2 & - & 2 & 2 & 2 & $<0.12$ & 0.12 & - \\
Oflaxocine & 0.12 & 1 & $<0.12$ & 0.12 & 0.12 & 0.5 & 0.5 & - \\
Ketocanazole & - & - & - & - & - & - & - & 2 \\
\hline
\end{tabular}

Table 2. Antiviral activity of the tested alkaloids

\begin{tabular}{|c|c|c|c|c|c|c|}
\hline \multicolumn{4}{|c|}{$\begin{array}{c}\text { MDBK Cells } \\
(\mu \mathrm{g} / \mathrm{ml})\end{array}$} & \multicolumn{3}{|c|}{$\begin{array}{c}\text { Vero Cells } \\
(\mu \mathrm{g} / \mathrm{ml})\end{array}$} \\
\hline \multirow{3}{*}{ Alkaloids } & \multirow{3}{*}{$\begin{array}{l}\text { MNTC } \\
(\mu \mathrm{g} / \mathrm{ml})\end{array}$} & \multirow{2}{*}{\multicolumn{2}{|c|}{$\begin{array}{c}\text { CPE Inhibitory } \\
\text { Concentration }\end{array}$}} & \multirow{3}{*}{$\begin{array}{l}\text { MNTC } \\
(\mu \mathrm{g} / \mathrm{ml})\end{array}$} & \multirow{2}{*}{\multicolumn{2}{|c|}{$\begin{array}{c}\text { CPE Inhibitory } \\
\text { Concentration }\end{array}$}} \\
\hline & & & & & & \\
\hline & & Max. & Min. & & Max. & Min. \\
\hline Lycoctonine & 64 & - & - & 32 & 32 & 8 \\
\hline 18-OMethyllycoctonine & 64 & - & - & 64 & 32 & 1 \\
\hline Delcosine & 64 & - & - & 64 & 32 & 1 \\
\hline 14-Acetyldelcosine & 64 & - & - & 64 & 32 & 1 \\
\hline 14-Acetylbrowniine & 64 & - & - & 64 & 32 & 1 \\
\hline Acyclovir & 16 & 16 & $<0.25$ & - & - & - \\
\hline Oseltamivir & . & - & - & 32 & 32 & $<0.25$ \\
\hline
\end{tabular}

Likewise, in a recent study, the roots of $A$. kusnezofii were shown to be teratogenic to fetus in rats. $^{7}$ In another study, bioassay-guided fractionation of the methanolic extract of A. pseudolaeve var. erectum led to isolation of a diterpene alkaloid, lycaconitine as an active principle, against multidrug resistance (MDR) human fibrocarcinoma KB V20C. ${ }^{6}$ In a study by Salimov ${ }^{8}$, the toxic and antiarrhythmic activities of the diterpene alkaloids from Aconitum zeravschanicum were analyzed, which led to the statement that activity and toxicity depended on the type of skeleton, the nature and positions of substituents, and the basicity of the nitrogen atom. A quantitative structure-activity relationships (QSAR) analysis performed on a number of diterpene alkaloids isolated from an Aconitum sp. indicated that biological activity of these alkaloids may be related to their toxicity rather than to a specific pharmacological action. ${ }^{9}$

In a current study on 43 norditerpenoid alkaloids from Consolida, Delphinium, and Aconitum species against several tumor cell lines, lycoctonine and browniine were found to be active among those screened. ${ }^{10}$ In contrary to this data, lycoctonine and the 14-acetyl derivative of 
browniine in our study showed a lesser amount of cytotoxicity on MDBK and Vero cell lines at $64 \mu \mathrm{g} / \mathrm{ml}$. Gonzales-Coloma et al. ${ }^{11}$ studied antifeedant activity and toxicity of some diterpene alkaloids (15-acetylcardiopetamine, cardiopetamine along with its amino alcohol, the beta, gamma unsaturated ketone, and the acetylated ketone derivatives) from Delphinium sp. on the insects Spodoptera littoralis and Leptinotarsa decemlineata. The results of the study showed that the $\mathrm{C} 13$ and $\mathrm{C} 15$ hydroxy substituents are essential features of the active molecule, while the C11 benzoate group enhanced the biological effect on both insect species for their structureactivity relationship, where all of our alkaloids lacked of those two substituents.

In a taxonomic study ${ }^{12}$, lycoctonine-type of alkaloids isolated from three Delphinium species were classified into three groups according to the degree of their toxicity as $N$-(methylsuccinyl)anthranoyllycoctonine (MAL)-type with high toxicity, lycoctonine-type with moderate toxicity, as well as 7,8-methylene-dioxylycoctonine (MDL)-type with low toxicity. In that paper, it was reported that the moiety attached to $\mathrm{C} 14$ is quite important for the toxicity of these alkaloids, which is also consistent with our present data. Furthermore, other functionalities on these molecules are also notable in terms of toxicity. It was found that the tertiary nitrogen, anthranilic acid substitution, and $\mathrm{C} 1$ moiety affects the toxicity degree within those alkaloids. For instance; when the methylsuccinyl group is removed from MAL (which then converts to lycoctonine), lycoctonine becomes 93 times less toxic.

Additionally, there is one report on antimicrobial activity of the methanolic extracts of two Consolida species of Iranian origin. ${ }^{13}$ According to the data they obtained; $C$. orientalis was significantly active against $B$. subtilis and Morganella morganii, while C. rugulosa showed a worth-mentioning inhibition towards E. coli and C. albicans. Without any doubt, the difference between their antimicrobial activities could be due to different phytochemical content, particularly in conjunction with their diterpene alkaloidal compounds.

Even though much is already known about toxicity of diterpene alkaloids that contribute to the toxicity of Consolida, Delphinium, and Aconitium species, no antiviral study has been so far reported on these-type alkaloids hitherto. Moreover, it is worth highlighting one of our past screening studies which described the antiviral effect of $C$. hellespontica against Sindbis virus and HSV. ${ }^{14}$ Interestingly, 50\% ethanolic extract prepared from this plant did not exert any inhibition in those tests. For that reason, the alkaloids from Consolida in our study were also completely inactive against HSV.

Our results showed that the alkaloids (1-5) possess rather high antifungal activity against $C$. albicans and a compelling antibacterial effect only against $K$. pneumoniae and A. baumannii, while they exert a strong inhibition against PI-3. This is the first report of antiviral, antibacterial, and antifungal activities of lycoctonine, 18-O-methyllycoctonine, delcosine, 14-acetyldelcosine, and 14-acetylbrowniine. Furthermore, our data also suggest that all of the diterpene alkaloids are worthy of being evaluated in regard to their antimicrobial and antiviral activities for promising results. 


\section{Experimental Section}

\section{Materials and methods}

Tested alkaloids - The extraction, isolation, and purification procedures for these alkaloids (1-5) were beforehand described in our earlier papers. ${ }^{15}$

Microorganisms - Standard strains of bacteria including Escherichia coli (ATCC 35218), Pseudomonas aeruginosa (ATCC 10145), Proteus mirabilis (ATCC 7002), Staphylococcus aureus (ATCC 25923), Bacillus subtilis (ATCC 6633), Klebsiella pneumoniae (RSKK 574), and Acinetobacter baumannii (RSKK 02026) (RSSK: Culture Collection of Refik Saydam Central Hygiene Institute, Ankara, Turkey) for determination of antibacterial activity and standard strain of the yeast-like fungus Candida albicans (ATCC 10231) for assessment of the antifungal activity were employed. In order to determine the antiviral action, Herpes simplex virus (HSV) and Parainfluenza-3 virus (PI-3) were provided by Department of Virology, Faculty of Veterinary, Ankara University (Turkey).

Antibacterial and antifungal activities - The diterpene alkaloids tested (1-5) were dissolved in ethanol/hexane $(1 / 1, \mathrm{v} / \mathrm{v})$ by using $1 \%$ Tween 80 solution at a final concentration of $1024 \mu \mathrm{g} / \mathrm{ml}$, sterilized by filtration using $0.22 \mu \mathrm{m}$ Millipore (MA, USA), and were used as the stock solutions. Standard antibacterial powders of ampicilline (AMP, Fako Pharmaceutical Company, Istanbul, Turkey) and ofloxacine (OFX, Hoechst Marion Roussel, Istanbul, Turkey) along with standard antifungal powder of ketacanazole (KET, Bilim Pharmaceutical Company, Istanbul, Turkey) were obtained from the respective manufacturers and dissolved in phosphate buffer solution (AMP, pH 8.0, $0.1 \mathrm{~mol} / \mathrm{l}$ ), dimethylsulphoxide (DMSO) (for KET), and water (for OFX). The stock solutions of the agents were prepared in medium according to the NCCLS recommendations. ${ }^{16}$

The microdilution method was used for antibacterial and antifungal activity tests. Media were placed into each well of the microplate. Compound solutions at $1024 \mu \mathrm{g} / \mathrm{ml}$ were added into first raw of microplates and 2-fold dilutions of the compounds $(512-0.25 \mu \mathrm{g} / \mathrm{ml})$ were made by dispensing the solutions to the remaining wells. $10 \mu \mathrm{l}$ of culture suspensions were inoculated into all the wells. The sealed microplates were incubated at $35^{\circ} \mathrm{C}$ for $24 \mathrm{hs}$ and $48 \mathrm{hs}$ in a humid chamber. The lowest concentrations of the compounds that completely inhibit macroscopic growth and minimum inhibitory concentrations (MICs) were determined. ${ }^{17-19}$

Mueller-Hinton Broth (Difco) and Mueller-Hinton Agar (Oxoid) were applied for growing and diluting of the bacteria. As for growing and diluting of the fungus, Sabouraud liquid medium (Oxoid) and Sabouraud dextrose agar (SDA) (Oxoid) were applied. The medium RPMI-1640 with $L$-glutamine was buffered to $\mathrm{pH}=7$ with 3 -( $N$-morpholino)-propansulfonic acid (MOPS). Prior to the tests, strains of bacteria and fungus were cultured on media and passaged at least twice to ensure purity and viability at $35{ }^{\circ} \mathrm{C}$ for 24 to $48 \mathrm{hs}$. Culture suspensions were prepared according to the NCCLS M27-A. ${ }^{16}$ The bacterial suspensions used for inoculation were prepared at $10^{5} \mathrm{cfu} / \mathrm{ml}$ by diluting fresh cultures at McFarland 0.5 density $\left(10^{8} \mathrm{cfu} / \mathrm{ml}\right)$. The fungus 
suspension was prepared by the spectrophotometric method of inoculum preparation at a final culture suspension of $2.5 \times 10^{3} \mathrm{cfu} / \mathrm{ml}$.

Antiviral activity and cytotoxicity evaluation - After the media (EMEM) were placed into each well of the 96-well microplates (Greiner ${ }^{\mathrm{R}}$, Germany), stock solutions of the alkaloids were added into first raw of microplates and 2-fold dilutions of the compounds (512-0.25 $\mu \mathrm{g} / \mathrm{ml})$, which were prepared according to $\log _{2}$ on the microplates, were made by dispensing the solutions to the remaining wells. Acyclovir (Biofarma, Istanbul, Turkey) and oseltamivir (Roche, Istanbul, Turkey) were employed as the references. Strains of HSV and PI-3 titers were calculated as TCID $_{50}$ and inoculated into all the wells. ${ }^{20}$ The sealed microplates were incubated in $5 \% \mathrm{CO}_{2}$ at $37^{\circ} \mathrm{C}$ for $2 \mathrm{hs}$ to detect the possible antiviral activities of the samples. Following incubation, 50 $\mu \mathrm{l}$ of the cell suspension of 300.000 cells $/ \mathrm{ml}$, which were prepared in EMEM together with $5 \%$ fetal bovine serum, were put in each well and the plates were incubated in $5 \% \mathrm{CO}_{2}$ at $37{ }^{\circ} \mathrm{C}$ for 48 hs. After that, the cells were evaluated using a cell culture microscope, comparing with treated-untreated control cultures and with acyclovir and oseltamivir. Consequently, maximum cytopathogenic effect (CPE) concentrations as the indicator of antiviral activities of the compounds were determined.

The maximum non-toxic concentration (MNTC) of each compound was determined by the method described beforehand based on cellular morphologic alteration. Several concentrations of each sample were placed in contact with confluent cell monolayer and incubated in $5 \% \mathrm{CO}_{2}$ at $37{ }^{\circ} \mathrm{C}$ for 48 hs. MNTC value for each compound was determined by comparing treated and controlling untreated cultures.

\section{References}

1. Gonzalez-Coloma, A.; Reina, M.; Guadano, A.; Santana, O.; Gavin, J.A.; Medinaveitina, A.; Ruiz-Mesia, L.; Grandez, M.; Alva, A.; De La Fuente, G. J. Chem. Ecol. 2004, 30, 1393.

2. Ralphs, M.H.; Olsen, J.D.; Pfister, J.A.; Manners, G.D. J. Anim. Sci. 1988, 66, 2334.

3. Ralphs, M.H.; Manners, G.D.; Pfister, J.A.; Gardner, D.R.; James, L.F. J. Range Manag. 1997, 50, 497.

4. Feng, H.T.; Li, S.F.Y. J. Chrom. A 2002, 973, 243.

5. Welsh, S.L.; Ralphs, M.H. Biochem. System. Ecol. 2002, 30, 103.

6. 6. (a) Olsen, J.D.; Sisson, D.V. Toxicol. Lett. 1991, 56, 33. (b) Kim, D.K.; Kwon, H.Y.; Lee, K.R.; Rhee, D.K.; Zee, O.P.. Arch. Pharm. Res. 1998, 21, 344. (c) Rodriguez, I.I.; Rodriguez, A.D. J. Nat. Prod. 2003, 66, 855. (d) Memg, Z.; Ding, Y.; Lu, J.; Zhao, Y.N.; Zhang, Y.M.; Tao, J.L.; Cheng, J.; Du, L.J. Chin. Pharmacol. Bull. 2004, 20, 801.

7. Xiao, K.; Li, H.X.; Wang, Y.Q.; Wang, L.; Peng, C.; Guo, L.; Liu, Y.Q. J. China Med. Univ. 2005, 6, 567.

8. Salimov, B.T.; Kuzibaeva, Z.K.; Dihakhangirov, F.N. Chem. Nat. Compds. 1996, 32, 366.

9. Bello-Ramirez, A.M., Nava-Ocampo, A.A. Fund. Clin. Pharmacol. 2004, 18, 699. 
10. De Inés, C.; Reina, M.; Gavín, J.A.; González-Coloma, A. Z. Naturforsc. C, 2006, 61, 11.

11. Gonzalez-Coloma, A.; Guadano, A.; Gutierrez, C.; Cabrera, R.; De La Pena, E.; De La Fuente, G.; Reina, M. J. Agric. Food Chem. 1998, 46, 286.

12. Panter, K.E.; Manners, G.D.; Stegelmeier, B.L.; Lee, S.; Gardner, D.R.; Ralphs, M.H.; Pfister, J.A.; James, L.F. Biochem. System. Ecol. 2002, 30, 113.

13. Bazzaz, B.S.F.; Harririzadeh, G. Pharm. Biol. 2003, 41, 573.

14. Hudson, J.B.; Lee, M.K.; Şener, B.; Erdemoğlu, N. Pharm. Biol. 2000, 38, 171.

15. 15. (a) Şener, B.; Bingöl, F.; Baykal, T. GUEDE- J. Fac. Pharm. Gazi 1988, 5, 79. (b) Şener, B.; Baykal, T.; Bingöl, F. GUEDE- J. Fac. Pharm. Gazi 1988, 5, 125. (c) Şener, B., Bingöl, F., Baykal, T. GUEDE- J. Fac. Pharm. Gazi 1989, 6, 1. (d) Desai, K.H.; Joshi, B.S.; Pelletier, S.W.; Şener, B.; Bingöl, F.; Baykal, T. Heterocycles 1993, 36, 1081. (e) Ulubelen, A.; Meriçli, A.H.; Meriçli, F.; Özçelik, H.; Şener, B.; Becker, H.; Zapp, J.; Choudhary, M.I.; Atta-Ur-Rahman. Phytochemistry 1999, 50, 909.

16. National Committee for Clinical Laboratory Standards. Method for broth dilution antifungal susceptibility testing yeast; approved standard, M27-A, 15, 10. NCCLS, Tucson, AZ, USA, 1996.

17. National Committee for Clinical Laboratory Standards. Methods for dilution antimicrobial susceptibility tests bacteria that grow aerobically, $3^{\text {rd }}$ ed., approved standard. NCCLS document M100-S12. NCCLS, Wayne, PA, USA, 2002.

18. Özçelik, B.; Aslan, M., Orhan, I.; Karaoğlu, T. Microbiol. Res. 2005, 160, 159.

19. Özçelik, B.; Citak, S.; Cesur, S.; Abbasoğlu, U.; Icli, F. Drug Med. Drug Interact. 2004, 20, 5 .

20. Frey, H.R.; Liess, B. J. Vet. Med. Ser. B 1971, 18, 61. 